\title{
Surface carboxylation or PEGylation decreases CuO nanoparticles' cytotoxicity to human cells in vitro without compromising their antibacterial properties
}

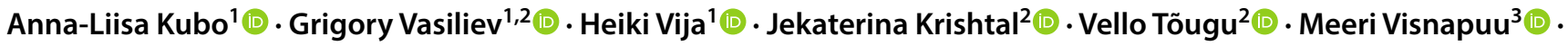 \\ Vambola Kisand ${ }^{3}\left[\right.$ [D Anne Kahru, ${ }^{1,4}$. Olesja M. Bondarenko' ${ }^{1}$
}

Received: 31 January 2020 / Accepted: 26 March 2020 / Published online: 7 April 2020

(c) The Author(s) 2020

\begin{abstract}
Clinical use of $\mathrm{CuO}$ nanoparticles (NPs) as antibacterials can be hampered by their toxicity to human cells. We hypothesized that certain surface functionalizations of $\mathrm{CuO}$ NPs may render NPs toxic to bacteria, but still be relatively harmless to human cells. To control this hypothesis, the toxicity of differently functionalized CuO NPs to bacteria Escherichia coli vs human cells (THP-1 macrophages and HACAT keratinocytes) was compared using similar conditions and end points. CuO NPs functionalized with polyethylene glycol (CuO-PEG), carboxyl ( $\mathrm{CuO}-\mathrm{COOH}$, anionic), ammonium $\left(\mathrm{CuO}_{-} \mathrm{NH}_{4}{ }^{+}\right.$, cationic) and unfunctionalized $\mathrm{CuO} \mathrm{NPs}$ and $\mathrm{CuSO}_{4}$ (controls) were tested. In general, the toxicity of $\mathrm{Cu}$ compounds decreased in the following order: $\mathrm{CuO}-\mathrm{NH}_{4}{ }^{+}>$unfunctionalized $\mathrm{CuO}>\mathrm{CuSO}_{4}>\mathrm{CuO}-\mathrm{COOH}>\mathrm{CuO}-\mathrm{PEG}$. Positively charged unfunctionalized $\mathrm{CuO}$ and especially $\mathrm{CuO}-\mathrm{NH}_{4}{ }^{+}$proved most toxic (24-h $\left.\mathrm{EC}_{50}=21.7-47 \mathrm{mg} / \mathrm{l}\right)$ and had comparable toxicity to bacterial and mammalian cells. The multivariate analysis revealed that toxicity of these NPs was mostly attributed to their positive zeta potential, small hydrodynamic size, high $\mathrm{Cu}$ dissolution, and induction of reactive oxygen species (ROS) and TNF- $\alpha$. In contrast, $\mathrm{CuO}-\mathrm{COOH}$ and CuO-PEG NPs had lower toxicity to human cells compared to bacteria despite efficient uptake of these NPs by human cells. In addition, these NPs did not induce TNF- $\alpha$ and ROS. Thus, by varying the NP functionalization and Cu form (soluble salt vs NPs), it was possible to "target" the toxicity of Cu compounds, whereas carboxylation and PEGylation rendered $\mathrm{CuO}$ NPs that were more toxic to bacteria than to human cells envisaging their use in medical antibacterial products.
\end{abstract}

Keywords Surface coating $\cdot$ Nanosafety $\cdot$ Nanomedicine $\cdot$ Antibacterial $\cdot$ Immunotoxicity $\cdot$ Particle internalization

Electronic supplementary material The online version of this article (https://doi.org/10.1007/s00204-020-02720-7) contains supplementary material, which is available to authorized users.

Anne Kahru

anne.kahru@kbfi.ee

$\bowtie$ Olesja M. Bondarenko

olesja.bondarenko@kbfi.ee

1 Laboratory of Environmental Toxicology, National Institute of Chemical Physics and Biophysics, Akadeemia tee 23, Tallinn, Estonia

2 Department of Chemistry and Biotechnology, School of Science, TalTech, Akadeemia tee 15, Tallinn, Estonia

3 Institute of Physics, University of Tartu, W. Ostwaldi 1, Tartu, Estonia

4 Estonian Academy of Sciences, Kohtu 6, Tallinn, Estonia

\section{Introduction}

Increasing resistance of bacteria to conventional antibiotics necessitates the development of alternatives such as silver and copper-based antimicrobials, including in nanoformulations. Copper is known since long time as a metal with antibacterial effect that can be used to inhibit bacterial spreads by employing $\mathrm{Cu}$ on surfaces (Rosenberg et al. 2018), in aqueous suspension (Bastos et al. 2018) and in textiles (Teli and Sheikh 2013; Mantecca et al. 2017). For living organisms, including humans, $\mathrm{Cu}$ is an essential microelement. $\mathrm{Cu}$ is vital for, e.g., functioning of the innate and adaptive immune system (Percival 1995, 1998) and is the necessary component of the key enzymes (O'Dell 1976). Previous studies have shown that $\mathrm{CuO}$ NPs support wound healing (Borkow et al. 2010) and bone regeneration (Shi et al. 2016). For instance, mesoporous silica NPs containing $2.5-5 \% \mathrm{Cu}$ 
were suggested for the use in bone regeneration, since they up-regulated the genes contributing to osteogenic and angiogenic factors and were not toxic in the range of $10-500 \mathrm{mg} / \mathrm{l}$ (i.e., $0.5-25 \mathrm{mg} \mathrm{Cu} / \mathrm{l}$ ) to murine macrophages RAW 264.7, whereas $\mathrm{Cu}$ significantly contributed to the beneficial properties of these NPs (Shi et al. 2016).

Given the above-mentioned properties, $\mathrm{CuO}$ NPs are ideal candidates for the use in medicine as wound dressings and/or internal implants by combining two functions: antimicrobial activity and increased wound healing or osteogenesis. However, the excessive copper is toxic and plays a role in the pathogenesis of several diseases (Klaassen and Curtis 2008; Brewer 2010; Montes et al. 2014). In case of topical use (e.g., in wound dressings), $\mathrm{CuO}$ NPs will be in close contact with keratinocytes and in case of internal use (e.g., implants), with the macrophages residing in the blood and tissues. Thus, it is important to avoid toxicity of $\mathrm{CuO}$ NPs to these cell types. Previous studies have shown that pristine (unfunctionalized) $\mathrm{CuO}$ NPs were toxic to murine macrophage cell line RAW264.7 (Líbalová et al. 2018) and other human cell models in vitro such as epidermal keratinocytes NHEK (Murugan et al. 2017), lung adenocarcinoma cells A549 (Karlsson et al. 2008), hepatoma cell line HepG2 (Piret et al. 2017), epithelial colon carcinoma cells Caco-2 (Käkinen et al. 2016) and differentiated Caco-2 (in vitro model for the cells of small intestine) (Ude et al. 2017) with the range of $\mathrm{EC}_{50}$ values of 13-100 mg/l (Bondarenko et al. 2013). However, the antibacterial concentrations of $\mathrm{CuO}$ NPs were in the range of $20-280 \mathrm{mg} / \mathrm{l}$, implying that the therapeutic use of the existing (mostly unfunctionalized) $\mathrm{CuO}$ NPs as antibacterials is rather limited, since the $\mathrm{CuO}$ NPs effective in killing bacteria were also toxic to human cells in vitro (Bondarenko et al. 2013, 2016). Thus, successful commercialization of antibacterial CuO NPs necessitates a compromise of reasonable antibacterial properties with reasonable safety to human cells. As the prerequisite of the toxic action of chemicals/NPs is adversely influencing or crossing the main biological barrier (the cell wall/membrane that is different in bacterial and mammalian cells), we hypothesized that certain type of surface functionalization of $\mathrm{CuO}$ NPs may render NPs toxic to bacteria, but still be relatively benign to human cells. Indeed, surface functionalization of metal-based NPs may change the safety profile of NPs (Nel et al. 2009; Kubo et al. 2018). For example, functionalization of NPs with PEG, chitosan or dextran prevented the opsonization of NPs (i.e., adsorption of biocorona of proteins and other biomolecules onto their surface) and, thus, reduced the uptake of NPs by macrophages and, hence, toxicity (Sheng et al. 2009; Jenkins et al. 2016; Wonder et al. 2018). In contrast, compared with NPs functionalized with neutrally (e.g., with PVP) or negatively charged coatings (e.g., citrate), functionalization of NPs with positively charged groups such as polyethylenimine (PEI), branched PEI or amine group rendered NPs that were more toxic to mammalian cells including murine macrophage cell line RAW264.7 (Líbalová et al. 2018), epithelial cells BEAS-2B and human monocytes THP-1 (Li et al. 2014).

While there are many articles on the biological effects of unfunctionalized $\mathrm{CuO}$, the information on differently functionalized $\mathrm{CuO}$ NPs is rare (Bondarenko et al. 2013; Juganson et al. 2015). Although there are various protocols available for the synthesis of $\mathrm{CuO}$ NPs functionalized with, e.g., peptides, antibodies and oligonucleotides (Tauran et al. 2013), these NPs were mostly intended for bioanalytical applications and thus not tested for their potential toxic effects. Our search in PubMed (performed in December 2019) using the keywords "copper nano* tox*" identified in total 215 research articles, and only 8 of these addressed the biological effects of differently functionalized $\mathrm{CuO} \mathrm{NPs}$ with the focus on the "green" functionalization such as chitosan (Worthington et al. 2013; Vanti et al. 2019), plant latex (Valodkar et al. 2011), albumin (Azizi et al. 2017) and a set of coatings including citrate, sodium ascorbate, polyvinylpyrrolidone, polyethylenimine (Líbalová et al. 2018) and, similarly to this study, carboxyl, PEG and ammonium (Meissner et al. 2019; Ilves et al. 2019). None of the studies compared the antibacterial properties of NPs with their safety to human cells in vitro or in vivo.

This study is the first report on the comparison of the antimicrobial efficiency and safety toward human cells of $\mathrm{CuO}$ NPs with different surface functionalizations: $\mathrm{CuO}-\mathrm{NH}_{4}{ }^{+}$, $\mathrm{CuO}-\mathrm{COOH}, \mathrm{CuO}-\mathrm{PEG}$ and unfunctionalized $\mathrm{CuO}$ NPs as well as $\mathrm{CuSO}_{4}$ as an ionic control. THP-1-derived macrophages were used as a model for immunotoxicity, HACAT keratinocytes in vitro as the model for human skin cells and Escherichia coli as model bacteria. We chose Gram-negative bacterium E. coli as there is a warning rise of multidrug resistance in Gram-negative bacteria becoming a challenge in health care (Exner et al. 2017). To minimize the effects of speciation of copper on test results, the toxicity of $\mathrm{Cu}$ compounds to THP- 1 cells and bacteria was tested in comparable conditions using RPMI medium supplemented with $10 \%$ fetal bovine serum and 24-h Alamar Blue to determine cell viability. In addition, we compared the potential mechanisms of toxicity of studied $\mathrm{Cu}$ compounds to different cell types with the focus on reactive oxygen species (ROS), dissolution, cellular internalization of $\mathrm{CuO}$ and their ability to induce inflammation in mammalian cells, and revealed the main parameters contributing to toxicity using statistical multivariate analysis.

\section{Materials and methods}

The manuscript does not contain clinical studies or patient data. 


\section{Chemicals}

All the purchased chemicals were at least of analytical grade. Dulbecco's phosphate-buffered saline (DPBS, Biognost), Alamar Blue (AppliChem), $\mathrm{CuSO}_{4}$ (Alfa Aesar), 2',7'-dichlorodihydrofluorescein diacetate $\left(\mathrm{H}_{2} \mathrm{DCF}-\mathrm{DA}\right.$, Life Technologies), phosphate buffered saline (PBS $\mathrm{pH}=7.2$, Biognost), tryptone (LabM), yeast extract (LabM), agar $(\mathrm{LabM})$ and $\mathrm{NaCl}$ (Sigma-Aldrich) were used.

\section{Nanoparticles}

Four types of differently functionalized and unfunctionalized $\mathrm{CuO}$ NPs were obtained via the consortium of EU FP7 project NANOSOLUTIONS (https://nanosolutionsfp7.com/) as a kind gift from Prof. Bengt Fadeel (Karolinska Institutet, Sweden). CuO NPs were synthesized by PlasmaChem (Germany) by decomposition of $\mathrm{Cu}_{2} \mathrm{CO}_{3}(\mathrm{OH})_{2}$, followed by the introduction of the surface groups via treatment with mercaptopropionic acid. $\mathrm{CuO}$ NPs were provided as dry powders, and the suspensions were prepared each time freshly before the tests at concentrations 1000-2000 mg compound/l in endotoxin free bi-distilled water (DI water). Ten milliliters of $\mathrm{CuO} \mathrm{NP}$ suspensions were vortexed and sonicated using probe sonication (Branson 450 Sonifier, USA) for $5 \mathrm{~min}$ with acoustic power of $13 \mathrm{~W}$ corresponding to the specific energy of $3.9 \cdot 10^{5} \mathrm{~kJ} / \mathrm{m}^{3}$ (Käkinen et al. 2016).

The morphology and primary size of NPs were studied using transmission electron microscope (TEM) Tecnai G2 Spirit BioTwin (FEI) at $120 \mathrm{kV}$. A drop of a $200 \mathrm{mg} / \mathrm{l} \mathrm{NP}$ suspension in methanol was deposited onto 200 mesh formvar/carbon coated copper grid (Agar Scientific, UK). Sixty particles were measured from TEM images using ImageJ software to obtain nanoparticle primary size. TEM figure for CuO-PEG was provided by NANOSOLUTIONS consortium (Fig. S1d).

Fourier transform infrared spectroscopy (FTIR) spectra were measured in the $1000-4000 \mathrm{~cm}^{-1}$ range with $2 \mathrm{~cm}^{-1}$ resolution using Bruker VERTEX 70 spectrometer with an attenuated total reflection (ATR) accessory.

Hydrodynamic size (Dh), polydispersity index (pdi) and zeta potential (Z-potential) of NPs were measured in $100 \mathrm{mg} / \mathrm{l}$ suspensions in DI water or cell culture medium using Malvern zetasizer (Zetasizer Nano-ZS, Malvern Instruments, UK).

The endotoxin content in $\mathrm{CuO}$ dispersions was assessed using the chromogenic Limulus amebocyte lysate (LAL) assay (Charles River Endosafe, Charleston, SC) according to the manufacturer's instructions and was below the detection limit of the assay.

The $\mathrm{Cu}$ content of the tested $\mathrm{Cu}$ compounds was determined using total reflection X-ray fluorescence (TXRF, Picofox S2, Bruker Corporation) from $100 \mathrm{mg} / \mathrm{l}$ suspensions.
Briefly, $40 \mu \mathrm{l}$ of the sample was mixed with $40 \mu \mathrm{l}$ of the reference element $(2 \mathrm{mg} / \mathrm{l} \mathrm{Ga})$ and $3 \mu \mathrm{l}$ of the mixture was pipetted onto quarts sample holder (Analyslide Petri Dish, Pall Corporation). The measurements were done in triplicate in at least two independent experiments.

For the dissolution analysis, $100 \mathrm{mg} / \mathrm{l} \mathrm{CuO} \mathrm{NPs}$ or $\mathrm{CuSO}_{4}$ (a recovery control) was incubated in cell culture medium (at $37{ }^{\circ} \mathrm{C}, 5 \% \mathrm{CO}_{2}$ and $95 \%$ humidity) for $0 \mathrm{~h}, 30 \mathrm{~min}$ or $24 \mathrm{~h}$ and centrifuged at $320,000 \times g$ for $30 \mathrm{~min}$ (Bekman Coulter ultracentrifuge). After centrifugation, the supernatants were collected and analyzed by TXRF as described above.

\section{Human cell lines}

The cell lines were obtained from American Type Culture Collection (ATCC) and cultured according to ATCC guidelines. The cells were subcultured up to 20 passages, and the toxicity tests were performed after at least two passages.

The human monocytic leukemia cell line THP-1 (ATCC TIB-202) was grown in Roswell Park Memorial Institute medium with L-glutamine (RPMI-1640, Corning) supplemented with $10 \%$ fetal bovine serum (FBS, Corning), $100 \mathrm{mM}$ sodium pyruvate solution (Na-Pyr, Gibco) and $10,000 \mathrm{U} / \mathrm{ml}$ penicillin and $10,000 \mu \mathrm{g} / \mathrm{ml}$ streptomycin (PEST, Gibco) that is further referred to as the complete cell culture medium (CCM). THP-1 cells (growing in suspension) were subcultured by adding fresh CCM. Before the assays, THP-1 cells were differentiated into macrophage like cells by culturing them with $100 \mathrm{ng} / \mathrm{ml}$ phorbol myristate acetate (PMA, InvivoGen) in CCM. For that, THP-1 cells were seeded into 96-well plates (Corning Falcon) at a density of $10^{5}$ cells per well and incubated with $100 \mathrm{ng} / \mathrm{ml}$ phorbol myristate acetate (PMA) for 3 days at $37^{\circ} \mathrm{C}$ and $5 \% \mathrm{CO}_{2}$.

The human HACAT cell line, immortalized keratinocytes (ATCC PCS-200-011), were grown in Dulbecco`s modified Eagle's medium with $4.5 \mathrm{~g} / \mathrm{l}$ glycose, L-glutamine and sodium pyruvate (DMEM, Corning) supplemented with $10 \%$ FBS and 1\% PEST. Before the tests, cells were seeded into 96-well plates at a density of $10^{4}$ cells per well and incubated for 1 day at $37{ }^{\circ} \mathrm{C}, 5 \% \mathrm{CO}_{2}$ and $95 \%$ humidity. The composition of the test media used is shown in Table S1.

\section{Bacterial cells}

Escherichia coli MG1655 (obtained from the E. coli genetic stock center, Yale University) and recombinant bioluminescent $E$. coli MC1061 (pSLcueR/pDNPcopAlux) [constructed in our laboratory previously (Ivask et al. 2009)] were stored on agarized Luria-Bertani medium (LB, $1 \%$ tryptone, $0.5 \%$ yeast extract, $0.5 \% \mathrm{NaCl}, 1.5 \%$ agar) and before the toxicity tests cultivated in $3 \mathrm{ml}$ of $\mathrm{LB}$ medium at $37{ }^{\circ} \mathrm{C}$ with shaking at $200 \mathrm{rpm}$ overnight. In case of recombinant bacteria, 
LB was supplemented with $100 \mu \mathrm{g} / \mathrm{l}$ ampicillin and $10 \mu \mathrm{g} / \mathrm{l}$ tetracycline to retain the bioluminescence-encoding plasmid.

\section{Toxicity assays}

The toxicity of $\mathrm{Cu}$ compounds to E. coli and THP-1 cells was assessed in similar conditions (24-h incubation in CCM medium at $37^{\circ} \mathrm{C}$ and using Alamar Blue assay for viability evaluation) with minor differences: (1) PEST was removed from E. coli exposure medium; (2) human cells were incubated in humidified conditions $\left(5 \% \mathrm{CO}_{2}\right)$. Details on the test conditions are summarized in Table S1. All reported concentrations were nominal and $\mathrm{EC}_{50}$ values were calculated either based on the compound (compound-based concentrations, Figs. 1a and S3, left panel) or on copper (copper-adjusted concentrations, Figs. 1c and S3, right panel) to estimate the contribution of $\mathrm{Cu}$ to the toxicity. The concentration of copper in $\mathrm{Cu}$ compounds was determined by TXRF as described above.

E. coli cells were grown in LB medium overnight, followed by removal of the medium by centrifugation and resuspension of bacterial pellet in CCM without PEST to $\sim 5 \times 10^{5}$ colony forming units $(\mathrm{CFU} / \mathrm{ml})$. For the toxicity assay, $100 \mu \mathrm{l}$ of bacterial suspension was exposed to $100 \mu \mathrm{l}$ of either cell culture medium (control) or $6.25-400 \mathrm{mg} / \mathrm{l}$ $\mathrm{CuO}$ suspensions $/ \mathrm{CuSO}_{4}$ in $\mathrm{CCM}$ in transparent 96-well plates for $24 \mathrm{~h}$ at $37^{\circ} \mathrm{C}$. The bacterial viability was estimated using Alamar Blue assay. For that, the exposed cells were washed and Alamar Blue (AppliChem, final concentration of $150 \mu \mathrm{g} / \mathrm{ml}$ ) in CCM without PEST was added to the cells for $2 \mathrm{~h}$ at $37^{\circ} \mathrm{C}$. After incubation, fluorescence was read by Fluoroscan (Fluoroskan Ascent FL, Thermo Labsystems) with excitation at $530 \mathrm{~nm}$ and emission at $590 \mathrm{~nm}$. The metabolic activity (viability) of the exposed cells was expressed in \% by comparing their fluorescence with that of untreated cells. The $\mathrm{EC}_{50}$ values were calculated as described in "Statistical analysis". Tests were performed in five biological experiments in duplicate. To assess possible interference of NPs with assay reagents, NPs with Alamar Blue were also incubated in abiotic conditions (no unspecific reactions were observed).

For the toxicity assay with human cells, the cell culture medium was removed, cells were washed with PBS and exposed to $100 \mu 1$ of either cell culture medium or $\mathrm{Cu}$ compounds in cell culture medium for $24 \mathrm{~h}$ at $37^{\circ} \mathrm{C}$ and $5 \% \mathrm{CO}_{2}$. After the exposure, the supernatant was removed, cells were washed once with PBS and incubated with $100 \mu \mathrm{l}$ of $150 \mu \mathrm{g} /$ $\mathrm{ml}$ Alamar Blue for $2 \mathrm{~h}$ at $37{ }^{\circ} \mathrm{C}$ and with $5 \% \mathrm{CO}_{2}$.

\section{Bioavailability of Cu to bacteria}

Quantification of intracellular $\mathrm{Cu}$ ions was performed using recombinant biosensor bacteria E. coli MC1061 (pSLcueR/
pDNPcopAlux) in which $\mathrm{Cu}$ ion-inducible promoter copA is genetically coupled to the bioluminescence-encoding genes luxCDABE (Ivask et al. 2009). Thus, bioluminescence of this recombinant $E$. coli increases in response to sub-toxic concentrations of intracellular $\mathrm{Cu}$ ions in a dose-dependent manner. In the toxic concentration range, the bioluminescence of bacteria gradually decreases.

The overnight bacterial culture was diluted 1:20 into fresh LB medium supplemented with $100 \mu \mathrm{g} / \mathrm{l}$ ampicillin and $10 \mu \mathrm{g} / \mathrm{l}$ tetracycline, grown till $\mathrm{OD}=0.5-0.8$ and diluted in CCM without PEST to OD $=0.1$ corresponding to a final concentration of $10^{6} \mathrm{CFU} / \mathrm{ml} .100 \mu \mathrm{l}$ of the appropriate dilution of $\mathrm{Cu}$ compounds in CCM without PEST was pipetted into the wells of white 96-well microplates and $100 \mu \mathrm{l}$ of bacterial culture in CCM without PEST was added. The test plates were incubated at $37^{\circ} \mathrm{C}$ for $2 \mathrm{~h}$, and bioluminescence was measured using Orion II plate luminometer (Berthold Detection Systems). Fold increase in bioluminescence in response to $\mathrm{Cu}$ compounds was calculated as a function of increased bioluminescence of biosensor in the sample $(\mathrm{CuO}$ and $\mathrm{CuSO}_{4}$ dilutions in CCM without PEST) compared to the background (CCM without PEST).

\section{Measurement of reactive oxygen species}

The ability of $\mathrm{CuO} \mathrm{NPs}$ and $\mathrm{CuSO}_{4}$ to generate ROS was measured in abiotic conditions in DI water with $\mathrm{H}_{2}$ DCFA-DA as described by Aruoja et al. (2015). $100 \mu \mathrm{l}$ of 6.25-200 mg/l CuO NPs and $\mathrm{CuSO}_{4}$ and $100 \mu \mathrm{l}$ of $\mathrm{H}_{2} \mathrm{DCF}$ were incubated at room temperature (RT) for $60 \mathrm{~min}$. Fluorescence (excitation at $485 \mathrm{~nm}$ and emission at $527 \mathrm{~nm}$ ) was quantified using a microplate fluorometer (Fluoroskan Ascent FL, Thermo Labsystems, Finland). The ability of $\mathrm{Cu}$ compounds to induce ROS was expressed in \% in relation to the control.

\section{Chemical analysis of cell-associated $\mathrm{Cu}$}

THP-1 monocytes were seeded into 96-well plates (Corning Falcon) at a density of $10^{5}$ cells/well and differentiated with $100 \mathrm{ng} / \mathrm{ml}$ PMA for $72 \mathrm{~h}$. Cells were exposed to $\mathrm{Cu}$ compounds in $\mathrm{CCM}$ at $\mathrm{EC}_{20}$ concentrations for $24 \mathrm{~h}(27.3 \mathrm{mg} / \mathrm{l}$ for CuO NPs, $22.2 \mathrm{mg} / \mathrm{l}$ for CuO-NH${ }_{4}^{+}, 90.6 \mathrm{mg} / \mathrm{l}$ for CuO$\mathrm{COOH}, 211.4 \mathrm{mg} / \mathrm{l}$ for $\mathrm{CuO}-\mathrm{PEG}$ and $85.4 \mathrm{mg} / \mathrm{l}$ for $\mathrm{CuSO}_{4}$ ).

HACAT cells were seeded into 96-well plates at density $10^{4}$ cells/well and allowed to attach for $24 \mathrm{~h}$. The cells were exposed to $\mathrm{Cu}$ compounds at $\mathrm{EC}_{20}$ concentrations $(11.6 \mathrm{mg} / \mathrm{l}$ for $\mathrm{CuO} \mathrm{NPs}, 14.9 \mathrm{mg} / \mathrm{l}$ for $\mathrm{CuO}-\mathrm{NH}_{4}{ }^{+}, 73.7 \mathrm{mg} / \mathrm{l}$ for $\mathrm{CuO}-\mathrm{COOH}, 142.0 \mathrm{mg} / \mathrm{l}$ for $\mathrm{CuO}-\mathrm{PEG}$ and $57.6 \mathrm{mg} / \mathrm{l}$ for $\mathrm{CuSO}_{4}$ ) for $24 \mathrm{~h}$.

After $24 \mathrm{~h}$ exposure, the cells were washed, detached and washed again twice with PBS by centrifugation at $150 \times g$ for 5 min. $10 \mu \mathrm{l}$ cell suspension was mixed with $10 \mu \mathrm{l}$ trypan 
blue and the cell number and cell viability were determined. The supernatant was aspirated and the pellet was lyophilized. The $\mathrm{Cu}$ content was quantified with TXRF, normalized on total cell number basis and designated as "cell-associated $\mathrm{Cu}$ ", referring to the sum of the following fractions: intracellular $\mathrm{Cu}$ and extracellular $\mathrm{Cu}$ bound to the cell surface.

\section{Measurement of TNF-a}

Differentiated THP- 1 cells at density $10^{5}$ cells/well were exposed to $\mathrm{CuO} \mathrm{NPs}$ and $\mathrm{CuSO}_{4}$ at concentrations from 25 to $400 \mathrm{mg} / \mathrm{l}$ in CCM. After 24-h exposure, the supernatants were collected, centrifuged for $10 \mathrm{~min}$ at $10,000 \times g$ and stored frozen at $-80^{\circ} \mathrm{C}$. TNF- $\alpha$ was measured on 96 -well plates using Enzyme-Linked Immunosorbent Assay (ELISA) kit (Invitrogen 88-7346) according to the manufacturer's instructions.

\section{Microscopy}

For the automatic photographing, THP-1 cells were differentiated in 24-well plates, exposed to NPs (24-h $\mathrm{EC}_{20}$ concentrations), washed, stained with Giemsa Stain (SigmaAldrich) according to manufacturer's instructions and visualized using Automated Digital Morphology System CellaVision ${ }^{\circledR}$. Before the analysis, differentiated THP- 1 cells were mixed with human red blood cells to improve the cell recognition by the software.

For the confocal microscopy, THP-1 cells were differentiated on glass coverslips in 12-well plates, stained with $5 \mu \mathrm{g} /$ $\mathrm{ml}$ Cell Mask Orange (CMO) cell membrane dye (Invitrogen), fixed with $4 \%$ paraformaldehyde (Sigma) and stained with 1:300 diluted DAPI (Sigma). Finally, the coverslips were rinsed and mounted with ProLong ${ }^{\circledR}$ Gold antifade reagent (Life Technologies) for 12-24 $\mathrm{h}$ at room temperature in the dark. Cells and NPs were visualized using a confocal microscope Zeiss Duo 510 META with $63 \times$ oil immersion objective 1.4 NA. To set up the reflectance optical configuration, the main beam splitter was set to NT80/20 and the channel was set up for reflectance using the $488 \mathrm{~nm}$ laser. CMO was excited with $561 \mathrm{~nm}$ laser and DAPI was visualized with $405 \mathrm{~nm}$ laser. Z-stacks from the coverslip to the top of the cell were acquired at a step size of $320 \mathrm{~nm}$. For three-dimensional (3D) reconstruction Imaris 6.4.2 software was used.

\section{Statistical analysis}

All tests were performed in at least three individual experiments in duplicate. The $\mathrm{EC}_{50}$ values were calculated using MS Excel macro Regtox (https://www.normalesup .org/ vindimian/en_download.html) and the results were presented with $95 \%$ confidence intervals. The statistical significance between the $\mathrm{EC}_{50}$ values was estimated assuming equal variances at $p<0.05$ with one-way ANOVA followed by Tukey`s HSD post hoc test. Heatmap and dendrogram were done with R Language and Environment for Statistical Computing (https://www.R-project.org). Heatmaps and dendrograms were generated using heatmap function (incorporating Euclidean distance and complete method).

Principal component analysis (PCA) was used to obtain a multiparametric estimation of the variables that contributed to the toxicity (average compound-based $\mathrm{EC}_{50}$ values) of $\mathrm{CuO}$ NPs. Scores of the first two PCs which accounted for $87-95 \%$ of the variance were used to generate the biplots. For visualization, data were scaled by dividing the (centered) columns of $x$ by their standard deviations.

\section{Results}

\section{Physico-chemical characterization of CuO NPs}

The primary sizes of CuO NPs were measured by transmission electron microscopy (TEM, Fig. S1) and the presence of the different organic functional groups on the functionalized NPs was verified with Fourier transform infrared spectroscopy (FTIR) (Fig. S2). CuO NPs mostly formed agglomerates of a few hundred nanometers with the primary particle sizes of $15.9 \pm 5.2,6.9 \pm 2.2,9.2 \pm 2.5$ and $12.1 \pm 3.2 \mathrm{~nm}$ for the $\mathrm{CuO}, \mathrm{CuO}-\mathrm{COOH}, \mathrm{CuO}-\mathrm{NH}_{4}{ }^{+}$and $\mathrm{CuO}-\mathrm{PEG}$ NPs, respectively (Fig. S1; Table 1).

FTIR spectra proved the presence of organic functional groups as absorption peaks characteristic to $\mathrm{O}-\mathrm{H}, \mathrm{C}-\mathrm{H}$, $\mathrm{C}=\mathrm{O}, \mathrm{N}-\mathrm{H}$ and $\mathrm{C}-\mathrm{O}$ vibrational bands were identified in the measured spectra (Fig. S2).

Hydrodynamic size (Dh) of NPs was in the range of $204 \mathrm{~nm}(\mathrm{CuO} \mathrm{NPs})$ to $1268 \mathrm{~nm}$ (CuO-PEG) (Table 1). The polydispersity index (pdi) values did not exceed 0.35 in the DI and increased to $0.45-0.88$ in the cell culture medium, confirming the tendency of NPs, especially $\mathrm{CuO}-\mathrm{PEG}$ (pdi=0.88), to agglomerate in the test medium. The Z-potential reflecting the particle surface charge in DI water was positive for $\mathrm{CuO}$ and $\mathrm{CuO}-\mathrm{NH}_{4}{ }^{+}$and negative for $\mathrm{CuO}-\mathrm{COOH}$ and $\mathrm{CuO}-\mathrm{PEG}$. In the cell culture medium, the Z-potential of NPs was negative for all the particles ranging from $-8.9 \mathrm{mV}\left(\mathrm{CuO}-\mathrm{NH}_{4}{ }^{+}\right)$to $-10.8 \mathrm{mV}(\mathrm{CuO})$, most likely due to the adsorption of the serum proteins (the $\mathrm{Z}$-potential of the test medium alone was $-10.4 \mathrm{mV}$ ) as suggested previously by Ivask et al. (2015) or the interference of the serum proteins [such as negatively charged bovine serum albumin tending to adsorb to the particles (Jachimska and Pajor 2012)] with the measurement. Measured total $\mathrm{Cu}$ content was the highest for $\mathrm{CuO}(76.8 \%)$, followed by $\mathrm{CuO}-\mathrm{NH}_{4}{ }^{+}(46.2 \%), \mathrm{CuO}-\mathrm{COOH}(33.6 \%)$ 
and $\mathrm{CuO}-\mathrm{PEG}(11.7 \%)$. The measured total $\mathrm{Cu}$ content in $\mathrm{CuSO}_{4}$ was $37.1 \pm 4.5 \%$, in agreement with the calculated amount of $\mathrm{Cu}$ in $\mathrm{CuSO}_{4}(39.8 \%)$, and $\mathrm{Cu}$ content in $\mathrm{CuO}$ was $76.8 \pm 5.7 \%$ close to the calculated amount of $\mathrm{Cu}$ in $\mathrm{CuO}$ (79.9\%) (Table 1).

\section{Toxicity of Cu compounds}

The loss of viability of the cells after 24-h exposure to different copper compounds is shown in Fig. S3. Figure 1 depicts the average 24-h $\mathrm{EC}_{50}$ values calculated on the basis of the dose-response curves from Fig. S3 (left panel) and dendrogram showing the clustering of these $\mathrm{EC}_{50}$ values (Fig. 1b). While the 24-h $\mathrm{EC}_{50}$ values of $\mathrm{CuSO}_{4}$ were very similar for all cell types, the toxicity of NPs to different cells significantly varied (Fig. 1a). Namely, unfunctionalized $\mathrm{CuO}$ and $\mathrm{CuO}-\mathrm{NH}_{4}{ }^{+}$were more toxic to human cells in vitro than to bacteria, whereas negatively charged $\mathrm{NPs}-\mathrm{CuO}-\mathrm{COOH}$ and $\mathrm{CuO}-\mathrm{PEG}$ - were significantly more toxic to bacteria compared to human cells. Thus, clearly, by varying the NP surface functionalization and also $\mathrm{Cu}$ form (soluble salt vs NPs), it was possible to tune the toxicity of $\mathrm{Cu}$ compounds to bacteria vs to human cells.

Dendrogram analysis of the average 24-h $\mathrm{EC}_{50}$ values pointed out several clusters: most toxic NPs-unfunctionalized $\mathrm{CuO}$ and $\mathrm{CuO}-\mathrm{NH}_{4}{ }^{+}$-clustered together, whereas $\mathrm{CuO}$ and $\mathrm{CuSO}_{4}$ formed another cluster and the least toxic CuO-PEG NPs a separate cluster (Fig. 1b). Since the most toxic NPs (unfunctionalized $\mathrm{CuO}$ and $\mathrm{CuO}-\mathrm{NH}_{4}{ }^{+} \mathrm{NPs}$ ) contained the highest \% of $\mathrm{Cu}$ (Table 1), the 24-h $\mathrm{EC}_{50}$ values of $\mathrm{Cu}$ compounds were re-calculated based on $\mathrm{Cu}$ content (from Table 1) and presented in Fig. 1c. Cu-adjusted $\mathrm{EC}_{50}$ of $\mathrm{CuSO}_{4}$ proved to be around $33 \mathrm{mg} \mathrm{Cu} / \mathrm{l}$ for all cell types. $\mathrm{Cu}$-adjusted $\mathrm{EC}_{50}$ values of $\mathrm{CuO} \mathrm{NPs} \mathrm{were} \mathrm{mostly} \mathrm{lower} \mathrm{or}$ the same as for $\mathrm{CuSO}_{4}$ depending on the surface functionalization and cell type showing that not only $\mathrm{Cu}$ contributed to the toxicity. Interestingly, $\mathrm{Cu}$-adjusted $\mathrm{EC}_{50}$ values clustered differently, highlighting that $\mathrm{CuO}-\mathrm{NH}_{4}^{+}, \mathrm{CuO}-\mathrm{PEG}$ and $\mathrm{CuO}-\mathrm{COOH}$ NPs are the most potent antibacterials (Fig. 1d). While $\mathrm{CuO}-\mathrm{PEG}$ and especially $\mathrm{CuO}-\mathrm{COOH}$
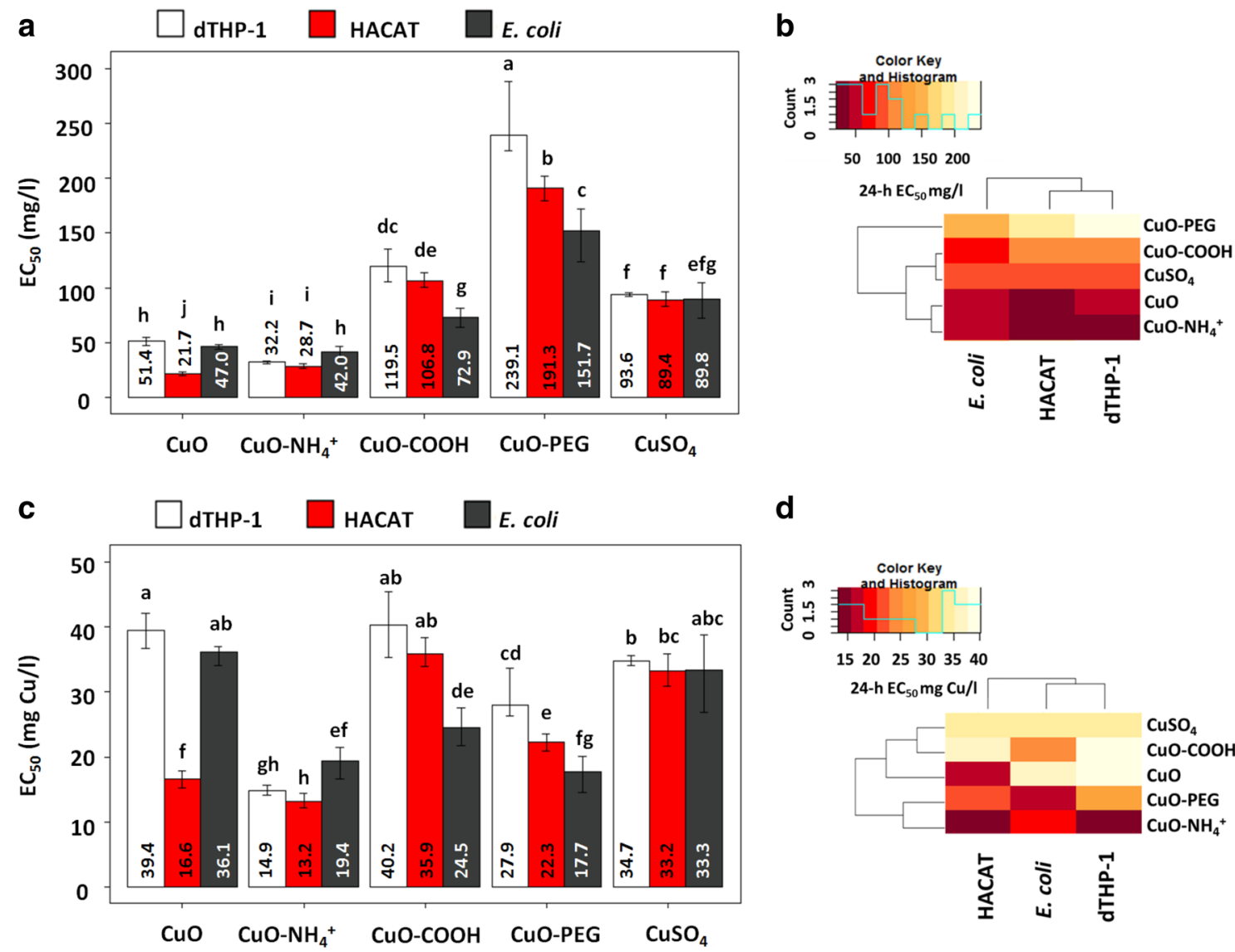

d

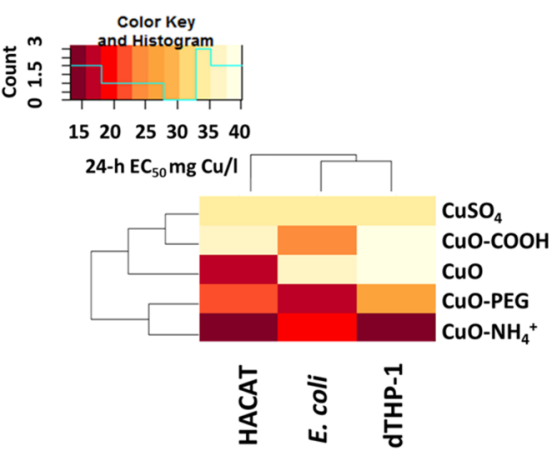

Fig. 1 Toxicity of $\mathrm{Cu}$ compounds to bacteria Escherichia coli (E. coli), HACAT keratinocytes and differentiated THP-1 cells (dTHP-1). The average compound-based 24-h $\mathrm{EC}_{50}$ values with $95 \%$ confidence intervals $\mathrm{mg} / \mathrm{l}$ (a) and the clustering of average compound-based 24-h $\mathrm{EC}_{50}$ (b). The average copper-adjusted 24-h $\mathrm{EC}_{50}$ values with $95 \%$ confidence intervals $\mathrm{mg} / \mathrm{l}$ (c) and the clustering of average copperadjusted 24-h $\mathrm{EC}_{50}(\mathbf{d})$. Data presented as bars with the same letters are not statistically significant, whereas data presented as bars with different letters are statistically significant 
Table 1 Physico-chemical characteristics of $\mathrm{Cu}$ compounds

\begin{tabular}{|c|c|c|c|c|c|c|}
\hline $\mathrm{Cu}$ compounds & Primary size, $\mathrm{nm}^{\mathrm{a}}$ & $\begin{array}{l}\text { Hydrodynamic diameter } \\
(\mathrm{Dh}) \text { in DI water }{ }^{\mathrm{b}} \mathrm{nm} \\
\left(\mathrm{pdi}^{\mathrm{c}}\right)\end{array}$ & $\begin{array}{l}\text { Dh in cell culture } \\
\text { medium }^{\mathrm{b}}, \mathrm{nm} \text { (pdi) }\end{array}$ & $\begin{array}{l}\text { Z-potential in } \\
\text { DI water }{ }^{b}, \mathrm{mV}\end{array}$ & $\begin{array}{l}\text { Z-potential in cell } \\
\text { culture medium } \\
\mathrm{mV}\end{array}$ & $\mathrm{Cu}$ content $^{\mathrm{d}}, \%$ \\
\hline $\mathrm{CuO}$ NPs & $15.9 \pm 5.2$ & $237 \pm 31(0.25)$ & $204 \pm 13(0.45)$ & $27.5 \pm 1.8$ & $-10.8 \pm 1.4$ & $76.8 \pm 5.7$ \\
\hline $\mathrm{CuO}-\mathrm{NH}_{4}{ }^{+} \mathrm{NPs}$ & $6.9 \pm 2.2$ & $733 \pm 252(0.24)$ & $936 \pm 229(0.67)$ & $25.8 \pm 1.3$ & $-8.9 \pm 0.8$ & $46.2 \pm 4.0$ \\
\hline $\mathrm{CuO}-\mathrm{COOH} \mathrm{NPs}$ & $9.2 \pm 2.5$ & $1124 \pm 128(0.35)$ & $303 \pm 84(0.70)$ & $-12.0 \pm 2.2$ & $-10.2 \pm 0.8$ & $33.6 \pm 3.2$ \\
\hline $\mathrm{CuO}-\mathrm{PEG}$ NPs & $12.1 \pm 3.2$ & $1244 \pm 254(0.35)$ & $1268 \pm 315(0.88)$ & $-21.9 \pm 3.3$ & $-10.0 \pm 1.8$ & $11.7 \pm 1.0$ \\
\hline $\mathrm{CuSO}_{4}$ & NA & NA & NA & NA & NA & $37.1 \pm 4.5$ \\
\hline
\end{tabular}

NA not applicable

${ }^{\mathrm{a}}$ Measured by transmission electron microscopy (TEM)

${ }^{\mathrm{b}}$ Measured by Malvern Zetasizer from $100 \mathrm{mg} / \mathrm{l}$ suspensions

${ }^{c}$ Polydispersity index

${ }^{\mathrm{d}}$ Analyzed by TXRF from $100 \mathrm{mg} / \mathrm{l}$ suspensions

NPs were less toxic to human cells compared to bacteria, $\mathrm{CuO}-\mathrm{NH}_{4}{ }^{+} \mathrm{NPs}$ were more toxic to mammalian cells. In addition, the Cu-based $\mathrm{EC}_{50}$ values of $\mathrm{CuO}-\mathrm{NH}_{4}{ }^{+} \mathrm{NPs}$ were about twice lower than that of $\mathrm{CuSO}_{4}$ (Fig. 1c), suggesting that the toxicity of $\mathrm{CuO}-\mathrm{NH}_{4}{ }^{+} \mathrm{NPs}$ cannot be solely explained by $\mathrm{Cu}$ content and additional toxicity mechanisms played a role in its toxicity. Thus, we determined the ability of $\mathrm{Cu}$ compounds to induce ROS in abiotic conditions and inflammation in mammalian cells and studied in detail their interactions with bacterial and human cells in vitro with the focus on NP localization and uptake mechanisms.

\section{Mechanisms of toxicity of Cu compounds}

\section{Bioavailability and dissolution of $\mathrm{Cu}$ compounds}

Recombinant bioluminescent $E$. coli increasing the bioluminescence in response to bioavailable $\mathrm{Cu}$ ions was applied to determine the role of internalized $\mathrm{Cu}$ ions in the antibacterial potency of $\mathrm{Cu}$ compounds (Fig. 2a). In parallel, chemical analysis was done to reveal dissolution of $\mathrm{CuO}$ (Fig. 2b). In the sub-toxic region, $\mathrm{Cu}$ compounds acted quite similar on sensor bacteria by increasing the bioluminescence of $E$. coli biosensor in parallel to the increase of the concentration of copper. There was, however, one exception: $\mathrm{CuO}-\mathrm{NH}_{4}{ }^{+} \mathrm{NPs}$ showed toxic properties (decline of luminescence) already at remarkably low concentrations (starting from $5 \mathrm{mg} \mathrm{Cu} / \mathrm{l}$ ), thus demonstrating the antibacterial effect independent of dissolved $\mathrm{Cu}$ ions (Fig. 2a). For other NPs, biosensor response was a function of $\mathrm{Cu}$ content and NP dissolution, being lowest for $\mathrm{CuO}$ (that had the lowest 0.5 -h dissolution, $40 \%$, Fig. 2b).

Thus, $\mathrm{Cu}$ biosensor suggested that $\mathrm{Cu}$ compounds exhibited antibacterial effects through bioavailable ionic $\mathrm{Cu}$ with the exception of $\mathrm{CuO}-\mathrm{NH}_{4}{ }^{+} \mathrm{NPs}$. In contrast, $\mathrm{CuO}-\mathrm{NH}_{4}{ }^{+}$ NPs were different from all the other $\mathrm{Cu}$ compounds by killing bacteria at remarkably low concentrations, even before the bioluminescence of biosensor was induced by $\mathrm{Cu}$. Thus, we hypothesized that $\mathrm{CuO}-\mathrm{NH}_{4}{ }^{+}$exhibits specific partly $\mathrm{Cu}$-independent antibacterial mechanism and studied the toxicity mechanisms of $\mathrm{CuO}-\mathrm{NH}_{4}{ }^{+}$and other NPs in more detail.

\section{Ability of Cu compounds to induce ROS and inflammation}

The results of the assay measuring abiotic ROS indicated that $\mathrm{CuO}-\mathrm{NH}_{4}{ }^{+} \mathrm{NPs}$ were very potent inducers of ROS (46fold induction at concentration $200 \mathrm{mg} / \mathrm{l}$ ), whereas other NPs were relatively poor ROS inducers (6- to 11-fold). $\mathrm{CuSO}_{4}$ did not induce ROS at any tested concentration (Fig. 3a). In addition, ELISA test revealed that $\mathrm{CuO}-\mathrm{NH}_{4}{ }^{+}$and also $\mathrm{CuO}$ NPs were the most potent inducers of TNF- $\alpha$ in differentiated THP- 1 cells inducing TNF- $\alpha$ already at $50 \mathrm{mg} / \mathrm{l}$, whereas $\mathrm{CuO}-\mathrm{COOH}$ and $\mathrm{CuSO}_{4}$ induced $\mathrm{TNF}-\alpha$ production starting from $100 \mathrm{mg} / \mathrm{l}$ (Fig. 3b) and CuO-PEG starting from $400 \mathrm{mg} / \mathrm{l}$ (data not shown). In general, TNF- $\alpha$ production correlated well with the $\mathrm{EC}_{50}$ numbers (Fig. 1a) and can be therefore considered as a marker of the cell death (Fink and Cookson 2005).

Using light microscopy, we also noticed extensive vacuolization in the cells exposed to $\mathrm{CuO}$ and especially to $\mathrm{CuO}-\mathrm{NH}_{4}{ }^{+} \mathrm{NPs}$ (Fig. 3c). Vacuolization has previously been suggested as a sign of inflammation and cell death (Shubin et al. 2016) and may indicate a distinct mechanism of toxicity of $\mathrm{CuO}-\mathrm{NH}_{4}{ }^{+} \mathrm{NPs}$ also in mammalian cells (macrophages) in vitro.

\section{Measurement of cell-associated $\mathrm{Cu}$ from $\mathrm{Cu}$ compounds}

To reveal the mechanisms of toxicity of $\mathrm{Cu}$ compounds, differentiated THP-1 cells and HACAT cells were exposed to 
equitoxic (24-h $\mathrm{EC}_{20}$ ) concentrations of $\mathrm{Cu}$ compounds for $24 \mathrm{~h}$, washed and analyzed for $\mathrm{Cu}$ content. We assumed that $\mathrm{Cu}$ content mostly referred to intracellular $\mathrm{Cu}$, but it cannot be excluded that some fraction of $\mathrm{CuO}$ NPs or dissolved $\mathrm{Cu}$ was tightly bound to cell surface and also detected by our analysis. Thus, the measured fraction was designated as "cell-associated $\mathrm{Cu}$ " combining intracellular $\mathrm{Cu}$ and $\mathrm{CuO}$ NPs and possible cell surface-bound $\mathrm{Cu}$. We hypothezised that (i) if the toxicity of $\mathrm{Cu}$ compounds was caused solely by $\mathrm{Cu}$ ions, the amount of cell-associated $\mathrm{Cu}$ in the cells exposed to equitoxic concentrations of $\mathrm{Cu}$ compounds would be equal; (ii) if the toxicity was caused by additional factors (as suggested for $\mathrm{CuO}-\mathrm{NH}_{4}^{+}$), the amount of cell-associated $\mathrm{Cu}$ would be lower compared to the other $\mathrm{CuO}$ NPs and $\mathrm{CuSO}_{4}$. The experiment proved the latter option: there was significantly less $\mathrm{Cu}$ in both differentiated THP- 1 and HACAT cells exposed to $\mathrm{CuO}-\mathrm{NH}_{4}{ }^{+}$, than in case of other exposures (Fig. 4a and Fig. S4). Surprisingly, we observed about five- and eightfold higher amounts of cell-associated $\mathrm{Cu}$ in case of $\mathrm{CuO}-\mathrm{COOH}$ compared to other NPs in both HACAT and differentiated THP-1 cells, respectively, suggesting that both cell lines had exceptional capacity to tolerate cell-associated $\mathrm{Cu}$ in the form of $\mathrm{CuO}-\mathrm{COOH}$. Therefore, we conducted the confocal microscopy study to confirm this result and visualize the cellular localization of $\mathrm{CuONPs}$.

\section{Cellular localization of Cu compounds in mammalian cells}

Differentiated THP-1 cells were exposed to equitoxic (24-h $\mathrm{EC}_{20}$ ) concentrations of $\mathrm{Cu}$ compounds for $24 \mathrm{~h}$ as in previous experiments and visualized with confocal microscopy (Figs. 4b, S5). The reflective mode of the microscope was optimized to visualize $\mathrm{CuO}$ NPs. However, some reflectance was seen also in a control group (shown in Fig. S5) that might be the dense inclusions of early lysosomes typical for macrophages (Douglas and Tuluc 2010). By combining Z-stacks into three-dimensional image, we observed that significantly more of $\mathrm{CuO}-\mathrm{COOH}$ NPs were associated with cells compared to other NPs (Fig. 4b). Furthermore, confocal microscopy images indicated that most of the $\mathrm{CuO}-\mathrm{COOH}$ NPs localized inside the cells (Supplementary video 1). Thus, the tolerance of THP-1 macrophages to internal $\mathrm{Cu}$ was exceptionally high for $\mathrm{CuO}-\mathrm{COOH}$ NPs and low for $\mathrm{CuO}-\mathrm{NH}_{4}{ }^{+} \mathrm{NPs}$. Interestingly, a similar phenomenon was previously shown for differently functionalized polystyrene NPs: the uptake of $\mathrm{COOH}$-functionalized NPs by human monocyte-derived macrophages as well THP-1 monocytes was significantly higher than the uptake of polystyrene- $\mathrm{NH}_{2}$ NPs (Lunov et al. 2011a), but despite that polystyrene- $\mathrm{NH}_{2}$ NPs were toxic to the macrophages after 72-h exposure, while polystyrene-COOH NPs were not toxic (Lunov et al. 2011b).

\section{Multivariate analysis for CuO}

Finally, multivariate analysis was performed to evaluate the variability of different properties of $\mathrm{CuO}$ NPs and, thus, to estimate their contribution to the net toxicity. For this, toxicity data (Fig. 1a) and physico-chemical characterization data (Table 1, Figs. 1, 3) were fitted into scores plot that comprises the eigenvectors. The principal component analysis (PCA) was applied resulting in NP positions according to their variability (Fig. 5).

Since arrows indicated the direction of the increase of the values, 24-h $\mathrm{EC}_{50}$ vector denoted the direction of lower toxicity (increasing $\mathrm{EC}_{50}$ value) that was the most characteristic for $\mathrm{CuO}-\mathrm{COOH}$ and $\mathrm{CuO}-\mathrm{PEG}$ (Fig. 5a-c). To estimate

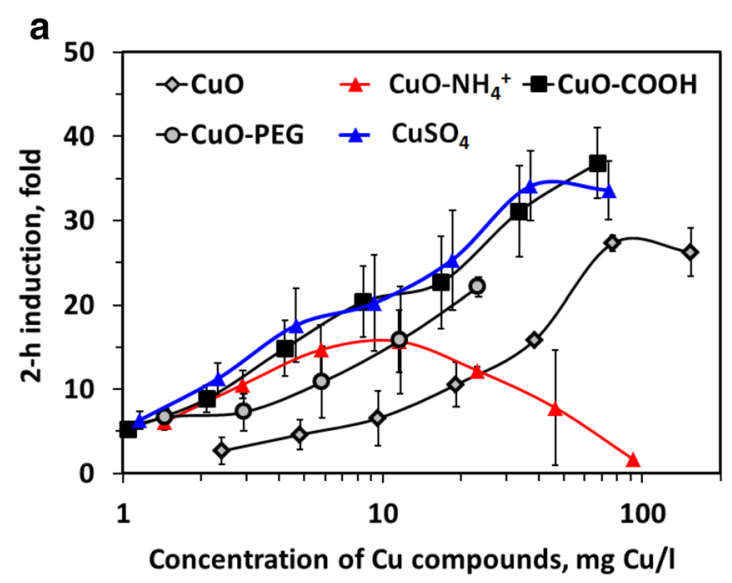

Fig. 2 Bioavailability and dissolution of $\mathrm{Cu}$ compounds. Induction of bioluminescence in $E$. coli biosensor in response to $\mathrm{Cu}$ compounds (a) and abiotic dissolution of $\mathrm{Cu}$ compounds in cell culture medium

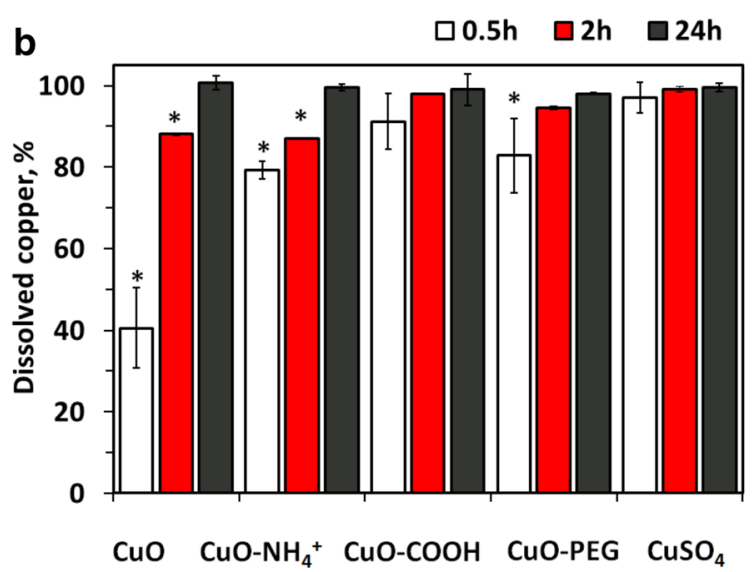

(100 mg/l, $\left.37^{\circ} \mathrm{C}\right)$ after $0.5,2$ and 24 -h incubation with standard deviations (b). Asterisks designate the statistically significant difference $(p<0.05)$ compared to the highest value in the group 
the contribution of different physico-chemical parameters to NPs` toxicity, we focused on the properties localizing in the area as opposed to the $\mathrm{EC}_{50}$ value vector. Figure 5 shows that the properties contributing to increased toxic effects of unfunctionalized $\mathrm{CuO}$ and $\mathrm{CuO}-\mathrm{NH}_{4}{ }^{+} \mathrm{NPs}$ were more positive zeta-potential, higher $\mathrm{Cu}$ content, higher 24-h dissolution, ability to produce more abiotic ROS and in case of THP-1 cells also higher production of TNF- $\alpha$. Importantly, the localization and the direction of the eigenvectors on the plot were strictly similar in case of mammalian cells (Fig. 5a, b) and bacteria (Fig. 5c), suggesting that the toxicity of $\mathrm{CuO}$ NPs to different cell types is influenced by the same variables.

\section{Discussion}

Antibacterial metal-based NPs such as $\mathrm{Ag}, \mathrm{ZnO}$ and $\mathrm{CuO}$ are usually purposely designed to inhibit the undesired growth of bacteria and are widely applied in medical and commercial products. However, it was shown that the toxicity range of $\mathrm{CuO}$ and $\mathrm{Ag}$ NPs to bacterial and mammalian cells in vitro may overlap, indicating the potential hazard of these NPs to human cells (Greulich et al. 2012; Bondarenko et al. 2013). In our comprehensive review on the toxicity of
$\mathrm{Ag}, \mathrm{ZnO}$ and $\mathrm{CuO}$ NPs to different organisms, we showed that among all studied NPs, CuO NPs had clear "particlespecific" toxic effect, i.e., NPs were more toxic than the $\mathrm{Cu}$ ions (on basis of $\mathrm{Cu}$ concentration) (Bondarenko et al. 2013). Among all organisms, this effect was only evident for mammalian cells in vitro and yeast cells.

That brought us to the current study: to test new surface functionalizations that would possibly render $\mathrm{CuO}$ NPs less toxic to mammalian cells than to bacterial cells. Despite wide commercial use and toxicity of $\mathrm{CuO}$ NPs, there were no attempts to identify the surface functionalizations of NPs that would decrease the cytotoxicity of NPs to human cells without compromising antibacterial functions.

In the current study, we compared the toxicity and revealed the mechanisms of toxicity of unfunctionalized $\mathrm{CuO} \mathrm{NPs}, \mathrm{CuO}-\mathrm{COOH}, \mathrm{CuO}-\mathrm{NH}_{4}{ }^{+}, \mathrm{CuO}-\mathrm{PEG}$ and $\mathrm{CuSO}_{4}$ to bacteria Escherichia coli and to human cells: HACAT keratinocytes and macrophages differentiated from THP-1 monocytes in vitro. Our main aim was to identify the NP surface functionalizations that would improve the safety profile of $\mathrm{CuO}$ NPs to mammalian cells in vitro, while retaining sufficient antibacterial activity. We showed that the effect of the surface functionalizations of CuO NPs on toxicity is different for bacteria and human cells. Namely, while the toxicity of ionic $\mathrm{CuSO}_{4}$ was nearly identical to bacterial
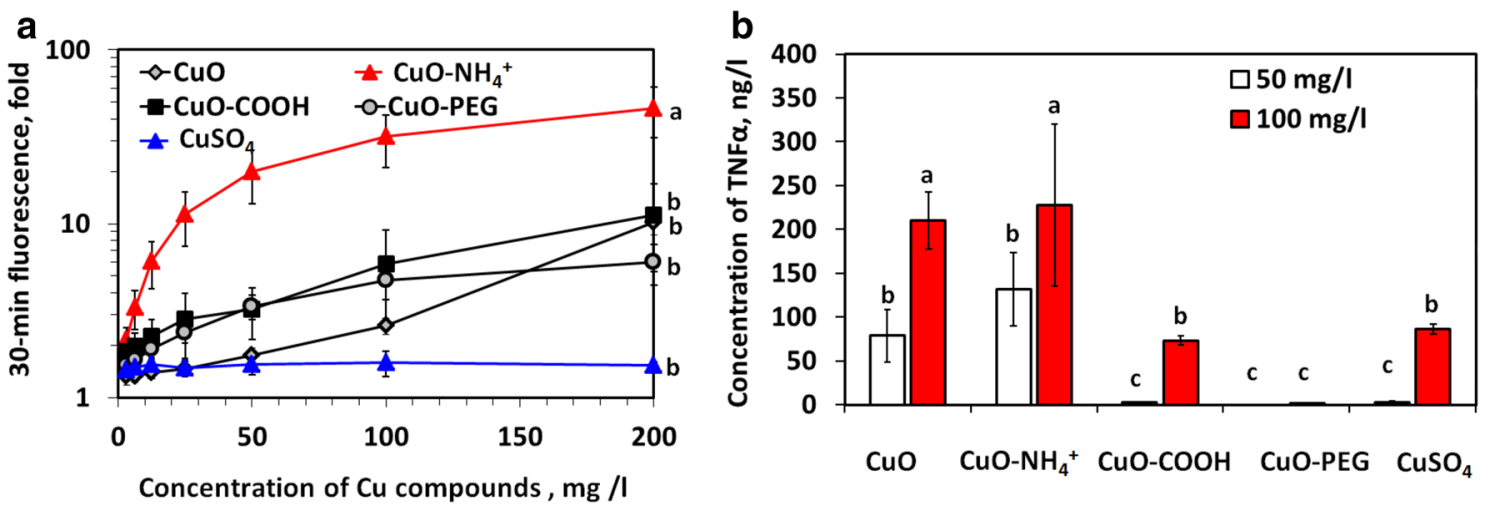

C control CuO CuO- $\mathrm{NH}_{4}^{+}$
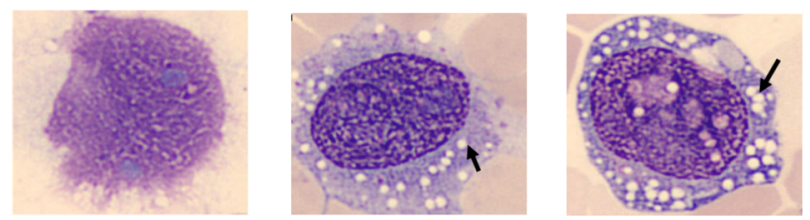

$\mathrm{CuO}-\mathrm{COOH}$

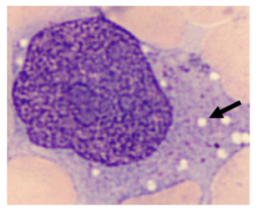

CUO-PEG

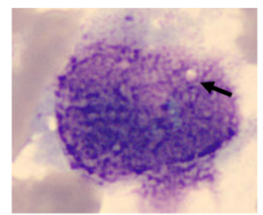

Fig. 3 Oxidative and inflammatory potential of $\mathrm{Cu}$ compounds. Fluorescence of $\mathrm{H}_{2}$ DCFA reflecting the ability of $\mathrm{Cu}$ compounds to produce reactive oxygen species in abiotic conditions in DI water (a). Concentrations of TNF- $\alpha$ in the supernatants of differentiated THP-1 cells exposed to $\mathrm{Cu}$ compounds in cell culture medium for $24 \mathrm{~h}(\mathbf{b})$ and representative light microscopy pictures of differentiated THP-1 cells exposed to equitoxic compound-based concentrations (24-h $\mathrm{EC}_{20}$ ) of $\mathrm{Cu}$ compounds for $24 \mathrm{~h}(\mathbf{c})$. Data presented as bars with the same letters are not statistically significant $(p>0.05)$ according to ANOVA analysis, whereas data presented as bars with different letters are statistically significant $(p<0.05)$. Arrows indicate localisation of the vacuoles 


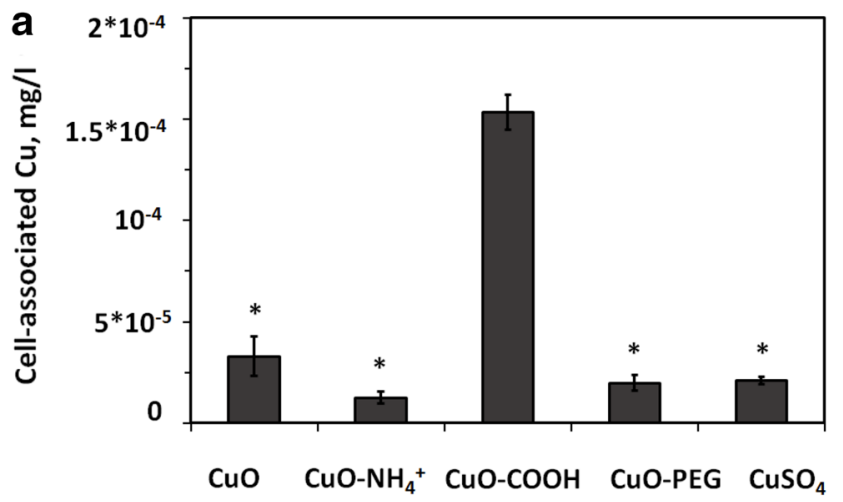

b
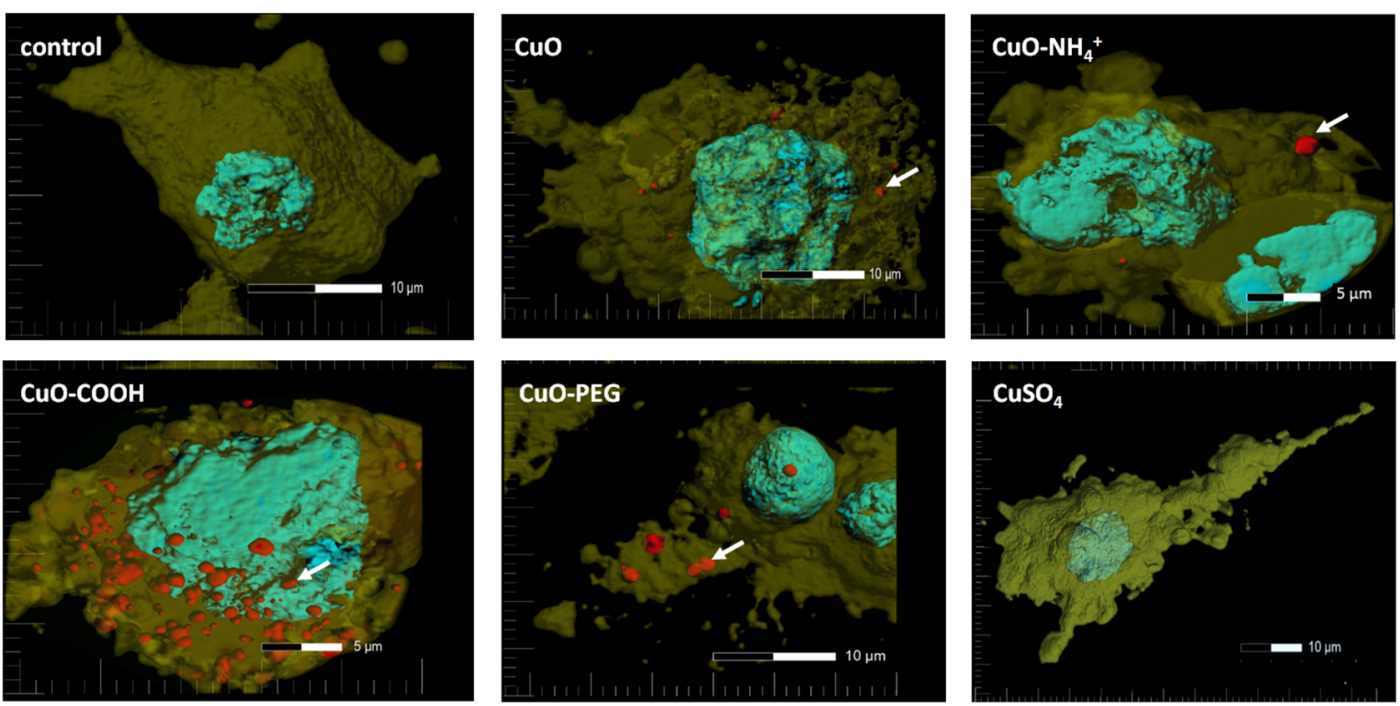

Fig. 4 Interaction of $\mathrm{Cu}$ compounds with THP-1 cells. Concentration of copper associated with differentiated THP-1 cells after 24-h exposure to the equitoxic $\left(\mathrm{EC}_{20}\right)$ concentrations of $\mathrm{CuO} \mathrm{NPs}$ and $\mathrm{CuSO}_{4}$ (a). Asterisks show the statistically different values $(p<0.001)$. Representative confocal microscopy images of differentiated THP-1 macrophages exposed to equitoxic concentrations (24-h $\left.\mathrm{EC}_{20}\right)$ of $\mathrm{Cu}$ com-

and human cells, $\mathrm{CuO}-\mathrm{COOH}$ and $\mathrm{CuO}-\mathrm{PEG}$ were significantly more toxic to bacteria than to human cells in vitro. In contrast, $\mathrm{CuO}-\mathrm{NH}_{4}{ }^{+}$was more toxic to human cells than to bacterial cells.

The effects of positively vs negatively charged nanomaterials to mammalian cells in vitro was previously addressed using, e.g., polystyrene NPs and carbon nanotubes. For example, it was shown that polystyrene- $\mathrm{NH}_{2}$ induced toxicity, lysosomal leakage and inflammasome activation and IL-1 $\beta$ production in primary human monocyte-derived macrophages (Loos et al. 2014), while polystyrene-COOH NPs were not toxic to the macrophages (Lunov et al. 2011b). In another study, carbon nanotubes functionalized with negatively charged $\mathrm{COOH}$ and PEG groups decreased the production of pro-fibrogenic pounds for $24 \mathrm{~h}$ (b). Cell membranes were stained with Cell Mask Orange (yellow) and cell nucleus with DAPI (blue). Nanoparticles were visualized in red using reflective mode of the microscope. The arrows indicate the cellular localisation of the $\mathrm{CuO}$ NPs (color figure online)

cytokines and growth factors in human cell lines BEAS$2 \mathrm{~B}$ and THP-1 compared to carbon nanotubes functionalized with $\mathrm{NH}_{2}$ or PEI (Li et al. 2014). In a recent study, it was shown that pristine, carboxylated and methylaminated, but not PEGylated, NPs worsened the pulmonary effects of $\mathrm{CuO}$ NPs in allergic airway inflammation mice model (Ilves et al. 2019). All these results are in line with our findings, showing that $\mathrm{NH}_{4}^{+}$functionalization renders $\mathrm{CuO}$ NPs that are especially toxic to human cells. Interestingly, from the studied NPs, $\mathrm{CuO}-\mathrm{NH}_{4}{ }^{+}$-functionalized NPs were also the most toxic to bacteria, indicating additional universal mechanisms of toxicity unrelated to the active NP uptake, lysosomal damage and inflammation (that are not existing in bacteria). Most probably, unspecific toxicity component of $\mathrm{CuO}-\mathrm{NH}_{4}{ }^{+}$was mediated via 
ROS (Fig. 3a) and binding to the cell surface (Fig. 4). Surprisingly, the most common unfunctionalized $\mathrm{CuO}$ NPs were almost as toxic as $\mathrm{CuO}-\mathrm{NH}_{4}{ }^{+} \mathrm{NPs}$ to human cells in vitro (Figs. 1, 5a,b), especially for HACAT cells (24-h $\mathrm{EC}_{50}=21.7 \mathrm{mg} / \mathrm{l}$, the lowest toxicity value obtained in this study). It was previously demonstrated that $24-\mathrm{h} \mathrm{EC}_{50}$ of unfunctionalized $\mathrm{CuO}$ NPs to HACAT was around $30 \mathrm{mg} / \mathrm{l}$ (MTT reduction assay), and that $\mathrm{CuO}$ induced ROS, oxidative stress, DNA damage and apoptosis in HACAT cells (Alarifi et al. 2013). In our study, CuO induced ROS tenfold in abiotic conditions, but at irrelevantly high concentration (200 mg/l, Fig. 3a). Furthermore, $\mathrm{CuO}-\mathrm{NH}_{4}{ }^{+}$ induced significantly more ROS, but was less toxic to HACAT than unfunctionalized $\mathrm{CuO}$, suggesting that ROSrelated mechanism was most likely not the primary mechanism of toxicity of unfunctionalized $\mathrm{CuO}$ to HACAT.

Our multivariate analysis of the properties contributing to the toxicity of $\mathrm{Cu}$ compounds revealed very similar patterns for mammalian cells in vitro and bacteria (Fig. 5). Zetapotential, $\mathrm{Cu}$ content, dissolution and ability to induce ROS were the most significant parameters defining toxicity to all cell types, suggesting that the toxicity mechanisms of $\mathrm{CuO}$ NPs to bacterial and mammalian cells are largely similar. Thus, in addition to the surface functionalization (that can modulate the specificity of $\mathrm{CuO}$ NPs to some extent as shown in this study), attention should be paid to the specific targeting of bacterial cells using bacterial cell wall componentsbinding peptides, antibiotics or their combinations with NPs to achieve more specificity and enlarged therapeutic window.

Summarizing, $\mathrm{CuO}-\mathrm{COOH}$ and $\mathrm{CuO}-\mathrm{PEG}$ NPs can be considered as promising antibacterials to be used in biomedical applications, since they were significantly more toxic to bacteria than to human cells in vitro. It is well known that functionalization of NPs with PEG prevents the adsorption of proteins and, thus, the uptake of NPs by macrophages (Nguyen and Lee 2017) that most likely explains the reduced toxicity of CuO-PEG NPs to mammalian cells in our study. The reason why mammalian cells were able to tolerate high intracellular concentration of $\mathrm{CuO}-\mathrm{COOH}$ NPs remains to be addressed. We speculate that $\mathrm{COOH}$ functionalization guides the NPs to the specific receptors and non-inflammogenic pathway, since it is known that NP interactions with the cell receptors impact their cellular localization, inflammatory properties and toxicity (Dobrovolskaia and McNeil 2007; Xia et al. 2008).

\section{Conclusions}

Here, we report the benefits of the surface functionalization of $\mathrm{CuO}$ with carboxyl- or polyethylene glycol compared to unfunctionalized and ammonium-functionalized $\mathrm{CuO}$ NPs. Specifically, we showed that $\mathrm{CuO}-\mathrm{NH}_{4}{ }^{+} \mathrm{NPs}$ were
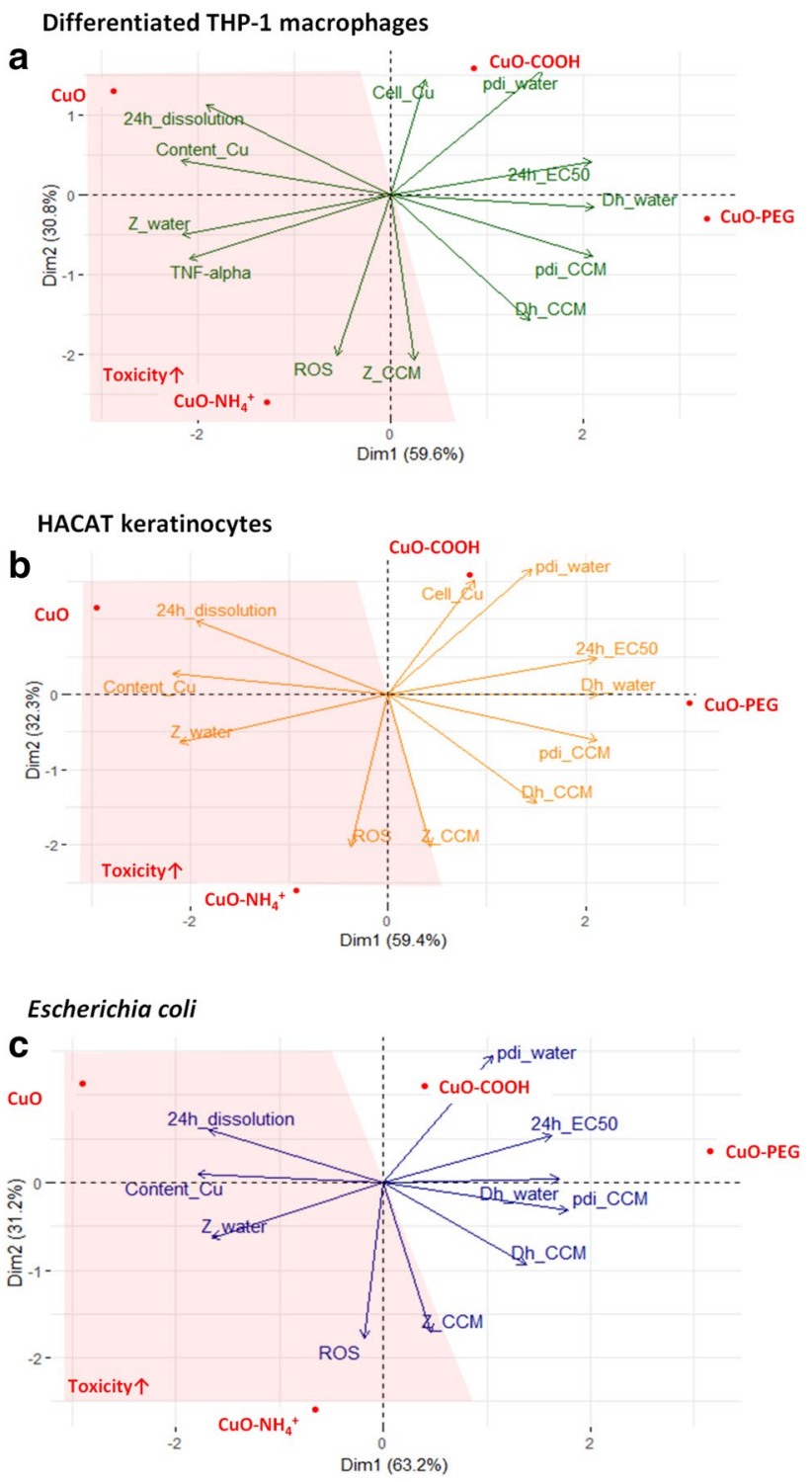

Fig. 5 Properties contributing to toxicity of $\mathrm{CuO}$ compounds. Multivariate analysis of properties contributing to the variability of the toxicity of $\mathrm{CuO}, \mathrm{CuO}-\mathrm{NH}_{4}{ }^{+}, \mathrm{CuO}-\mathrm{COOH}$ and $\mathrm{CuO}-\mathrm{PEG}$ NPs to differentiated THP-1 macrophages (a), E. coli (b) and HACAT keratinocytes (c). Z_water surface charge in distilled (DI) water, $Z_{-} C C M$ surface charge in cell culture medium, $\mathrm{Cell} \_\mathrm{Cu}$ cell-associated $\mathrm{Cu}$, $D h \_w a t e r$ hydrodynamic size in DI water, $D h \_C C M$ hydrodynamic size in cell culture medium, $p d i \_C C M$ pdi in cell culture medium, pdi_water pdi in water, ROS abiotic reactive oxygen species, Content_Cu copper content. More toxic compounds are highlighted in the red area (color figure online)

significantly more toxic to human cells in vitro than to $E$. coli cells, probably because of their ability to induce inflammation (TNF- $\alpha$ ) in human cells and ROS. The best therapeutic window was observed for $\mathrm{CuO}-\mathrm{COOH}$ and $\mathrm{CuO}-\mathrm{PEG}$ that can be recommended as antimicrobials.

Summarizing, we showed that the antibacterial potency vs safety profile of $\mathrm{CuO}$ NPs can be tuned with the surface 
functionalizations, and the effect of the surface functionalizations is different for bacteria and human cells. This knowledge can be used for the synthesis of more efficient and safer antimicrobials.

Acknowledgements This work was supported by the Estonian Research Council grants PUT1015, IUT23-5 and by European Regional Development Fund projects TK134, IMPAKT 2014-2020.4.01.16-0041 and NAMUR+2014-2020.4.01.16-0123. Olesja Bondarenko and AnnaLiisa Kubo were also supported by Graduate School in Clinical Medicine, receiving funding from the European Regional Development Fund under program ASTRA 2014-2020.4.01.16-0032. Dr. Carsten Jost, Dr. Alexei Antipov (PlasmaChem) and Prof. Bengt Fadeel (Karolinska Institutet, Sweden) are acknowledged for copper oxide nanoparticles, Dr. Aljona Lukjanova and Dr. Valeriy Verchenko (National Institute of Chemical Physics and Biophysics, Estonia) for the technical help with microscopy and consultations in material characterization, respectively; Dr. Taavi Päll (University of Tartu, Estonia) and Dr. Pekka Kohonen (Karolinska Institutet, Sweden) for the feedback on the multivariate analysis and Oleg Barotov (West Tallinn Central Hospital, Estonia) for the photographs of THP- 1 cells with the CellaVision.

Author contributions AL participated in planning, performed most of the experimental work, analyzed the data, prepared most of the figures and participated in writing, GV participated in planning, conducted experiments with mammalian cells and participated in writing, HV performed TXRF analysis and participated in writing, JK performed confocal microscopy and participated in writing, VT participated in writing, MV and VK performed and interpreted TEM and FTIR, AK participated in planning and refining of the writing, OB initiated and planned the study, performed microbiology experiments, wrote the draft and refined the manuscript. All authors approved the submitted version of the manuscript.

\section{Compliance with ethical standards}

Conflict of interest The authors declare no competing interests.

Open Access This article is licensed under a Creative Commons Attribution 4.0 International License, which permits use, sharing, adaptation, distribution and reproduction in any medium or format, as long as you give appropriate credit to the original author(s) and the source, provide a link to the Creative Commons licence, and indicate if changes were made. The images or other third party material in this article are included in the article's Creative Commons licence, unless indicated otherwise in a credit line to the material. If material is not included in the article's Creative Commons licence and your intended use is not permitted by statutory regulation or exceeds the permitted use, you will need to obtain permission directly from the copyright holder. To view a copy of this licence, visit http://creativecommons.org/licenses/by/4.0/.

\section{References}

Alarifi S, Ali D, Verma A et al (2013) Cytotoxicity and genotoxicity of copper oxide nanoparticles in human skin keratinocytes cells. Int J Toxicol 32:296-307. https://doi.org/10.1177/1091581813487563

Aruoja V, Pokhrel S, Sihtmäe M et al (2015) Toxicity of 12 metalbased nanoparticles to algae, bacteria and protozoa. Environ Sci Nano 2:630-644. https://doi.org/10.1039/c5en00057b

Azizi M, Ghourchian H, Yazdian F et al (2017) Cytotoxic effect of albumin coated copper nanoparticle on human breast cancer cells of MDA-MB 231. PLoS ONE 12:1-21. https://doi.org/10.1371/ journal.pone.0188639

Bastos CAP, Faria N, Ivask A et al (2018) Ligand-doped copper oxohydroxide nanoparticles are effective antimicrobials. Nanoscale Res Lett 13:2-8. https://doi.org/10.1186/s11671-018-2520-7

Bondarenko O, Juganson K, Ivask A et al (2013) Toxicity of Ag, CuO and $\mathrm{ZnO}$ nanoparticles to selected environmentally relevant test organisms and mammalian cells in vitro: a critical review. Arch Toxicol 87:1181-1200. https://doi.org/10.1007/s0020 4-013-1079-4

Bondarenko OM, Heinlaan M, Sihtmäe M et al (2016) Multilaboratory evaluation of 15 bioassays for (eco)toxicity screening and hazard ranking of engineered nanomaterials: FP7 project NANOVALID. Nanotoxicology 10:1229-1242. https://doi.org/10.1080/17435 390.2016.1196251

Borkow G, Gabbay J, Dardik R et al (2010) Molecular mechanisms of enhanced wound healing by copper oxide-impregnated dressings. Wound Repair Regen 18:266-275. https://doi.org/10.1111/j.1524475X.2010.00573.X

Brewer GJ (2010) Copper toxicity in the general population. Clin Neurophysiol 121:459-460. https://doi.org/10.1166/jbmb.2011.1121

Dobrovolskaia MA, McNeil SE (2007) Immunological properties of engineered nanomaterials. Nat Nanotechnol 2:469-478. https:// doi.org/10.1038/nnano.2007.223

Douglas SD, Tuluc F (2010) Morphology of monocytes and macrophages. In: Lichtman MA, Kipps TJ, Seligsohn U, et al. (eds) Williams hematology, 8th edn. The McGraw-Hill Companies, New York

Exner M, Bhattacharya S, Christiansen B et al (2017) Antibiotic resistance: what is so special about multidrug-resistant Gramnegative bacteria? GMS Hyg Infect Control 12:1-24. https://doi. org/10.3205/dgkh000290

Fink SL, Cookson BT (2005) Apoptosis, pyroptosis, and necrosis : mechanistic description of dead and dying eukaryotic cells. Infect Immun 73:1907-1916. https://doi.org/10.1128/IAI.73.4.1907

Gajda Meissner Z, Matyja K, Brown D et al (2019) Importance of surface coating on accumulation dynamics and acute toxicity of copper nanomaterials and dissolved copper to daphnia magna. Environ Toxicol Chem 00:1-13. https://doi.org/10.1002/etc.4617

Greulich C, Braun D, Peetsch A et al (2012) The toxic effect of silver ions and silver nanoparticles towards bacteria and human cells occurs in the same concentration range. RSC Adv 2:6981-6987. https://doi.org/10.1039/c2ra20684f

Ilves M, Kinaret PAS, Ndika J et al (2019) Surface PEGylation suppresses pulmonary effects of $\mathrm{CuO}$ in allergen-induced lung inflammation. Part Fibre Toxicol 16:1-21. https://doi.org/10.1186/ s12989-019-0309-1

Ivask A, Rõlova T, Kahru A (2009) A suite of recombinant luminescent bacterial strains for the quantification of bioavailable heavy metals and toxicity testing. BMC Biotechnol 9:1-15. https://doi. org/10.1186/1472-6750-9-41

Ivask A, Titma T, Visnapuu M et al (2015) Toxicity of 11 metal oxide nanoparticles to three mammalian cell types in vitro. Curr Top Med Chem 15:1914-1929. https://doi.org/10.2174/1568026615 666150506150109

Jachimska B, Pajor A (2012) Physico-chemical characterization of bovine serum albumin in solution and as deposited on surfaces. Bioelectrochemistry 87:138-146. https://doi.org/10.1016/j.bioel echem.2011.09.004

Jenkins SI, Weinberg D, Al-Shakli AF et al (2016) "Stealth" nanoparticles evade neural immune cells but also evade major brain cell populations: implications for PEG-based neurotherapeutics. J Control Release 224:136-145. https://doi.org/10.1016/j.jconr el.2016.01.013 
Juganson K, Ivask A, Blinova I et al (2015) NanoE-Tox: new and indepth database concerning ecotoxicity of nanomaterials. Beilstein J Nanotechnol 6:1788-1804. https://doi.org/10.3762/bjnano.6.183

Käkinen A, Kahru A, Nurmsoo H et al (2016) Solubility-driven toxicity of $\mathrm{CuO}$ nanoparticles to $\mathrm{Caco} 2$ cells and Escherichia coli: effect of sonication energy and test environment. Toxicol Vitr 36:172-179. https://doi.org/10.1016/j.tiv.2016.08.004

Karlsson HL, Cronholm P, Gustafsson J, Mo L (2008) Copper oxide nanoparticles are highly toxic a comparison between metal oxide nanoparticles and carbon nanotubes-chemical research in toxicology (ACS Publications). Chem Res Toxicol 21:1726-1732. https://doi.org/10.1021/tx800064j

Klaassen CD (ed) (2008) Casarett and Doull's Toxicology: the basic science of poisons, 7th edn. McGraw-Hill, New York

Kubo A-L, Capjak I, Vrček IV et al (2018) Antimicrobial potency of differently coated 10 and $50 \mathrm{~nm}$ silver nanoparticles against clinically relevant bacteria Escherichia coli and Staphylococcus aureus. Colloids Surfaces B Biointerfaces. https://doi. org/10.1016/j.colsurfb.2018.06.027

Li R, Wang X, Ji Z et al (2014) The surface charge and cellular processing of covalently functionalized multiwall carbon nanotubes determine pulmonary toxicity. ACS Nano 34:283-293. https://doi. org/10.1016/j.biomaterials.2012.09.057.Cell

Líbalová H, Costa PM, Olsson M et al (2018) Toxicity of surfacemodified copper oxide nanoparticles in a mouse macrophage cell line: interplay of particles, surface coating and particle dissolution. Chemosphere 196:482-493. https://doi.org/10.1016/j.chemo sphere.2017.12.182

Loos C, Syrovets T, Musyanovych A et al (2014) Amino-functionalized nanoparticles as inhibitors of mTOR and inducers of cell cycle arrest in leukemia cells. Biomaterials 35:1944-1953. https://doi. org/10.1016/j.biomaterials.2013.11.056

Lunov O, Syrovets T, Loos C et al (2011a) Differential uptake of functionalized polystyrene nanoparticles by human macrophages and a monocytic cell line. ACS Nano 5:1657-1669. https://doi. org/10.1021/nn2000756

Lunov O, Syrovets T, Loos C et al (2011b) Amino-functionalized polystyrene nanoparticles activate the NLRP3 inflammasome in human macrophages. ACS Nano 5:9648-9657. https://doi. org/10.1021/nn203596e

Mantecca P, Kasemets K, Deokar A et al (2017) Airborne nanoparticle release and toxicological risk from metal-oxide-coated textiles: toward a multiscale safe-by-design approach. Environ Sci Technol 51:9305-9317. https://doi.org/10.1021/acs.est.7b02390

Montes S, Rivera-mancia S, Diaz-ruiz A et al (2014) Review article copper and copper proteins in Parkinson's disease. Hindawi Publ 2014:1-15. https://doi.org/10.1155/2014/147251

Murugan K, Choonara YE, Kumar P et al (2017) Cellular internalisation kinetics and cytotoxic properties of statistically designed and optimised neo-geometric copper nanocrystals. Mater Sci Eng C 78:376-388. https://doi.org/10.1016/j.msec.2017.04.087

Nel AE, Mädler L, Velegol D et al (2009) Understanding biophysicochemical interactions at the nano-bio interface. Nat Mater 8:543-557. https://doi.org/10.1038/nmat2442

Nguyen VH, Lee BJ (2017) Protein corona: a new approach for nanomedicine design. Int J Nanomed 12:3137-3151. https://doi. org/10.2147/IJN.S129300

O'Dell BL (1976) Biochemistry of copper. Med Clin North Am 60:687-703. https://doi.org/10.1016/S0025-7125(16)31853-3
Percival SS (1995) Neutropenia caused by copper deficiency: possible mechanisms of action. Nutr Rev 53:59-66. https://doi. org/10.1111/j.1753-4887.1995.tb01503.x

Percival SS (1998) Copper and immunity. Am J Clin Nutr 67:10641068. https://doi.org/10.1093/ajcn/67.5.1064S

Piret JP, Bondarenko OM, Boyles MSP et al (2017) Pan-European inter-laboratory studies on a panel of in vitro cytotoxicity and pro-inflammation assays for nanoparticles. Arch Toxicol 91:23152330. https://doi.org/10.1007/s00204-016-1897-2

Rosenberg M, Vija H, Kahru A et al (2018) Rapid in situ assessment of $\mathrm{Cu}$-ion mediated effects and antibacterial efficacy of copper surfaces. Sci Rep 8:1-12. https://doi.org/10.1038/s41598-01826391-8

Sheng Y, Liu C, Yuan Y et al (2009) Long-circulating polymeric nanoparticles bearing a combinatorial coating of PEG and water-soluble chitosan. Biomaterials 30:2340-2348. https://doi. org/10.1016/j.biomaterials.2008.12.070

Shi M, Chen Z, Farnaghi S et al (2016) Copper-doped mesoporous silica nanospheres, a promising immunomodulatory agent for inducing osteogenesis. Acta Biomater 30:334-344. https://doi. org/10.1016/j.actbio.2015.11.033

Shubin AV, Demidyuk IV, Komissarov AA et al (2016) Cytoplasmic vacuolization in cell death and survival. Oncotarget. https://doi. org/10.18632/oncotarget.10150

Tauran Y, Brioude A, Coleman AW et al (2013) Molecular recognition by gold, silver and copper nanoparticles. World J Biol Chem 4:35. https://doi.org/10.4331/wjbc.v4.i3.35

Teli MD, Sheikh J (2013) Modified bamboo rayon-copper nanoparticle composites as antibacterial textiles. Int J Biol Macromol 61:302_ 307. https://doi.org/10.1016/j.ijbiomac.2013.07.015

Ude VC, Brown DM, Viale L et al (2017) Impact of copper oxide nanomaterials on differentiated and undifferentiated Caco- 2 intestinal epithelial cells; assessment of cytotoxicity, barrier integrity, cytokine production and nanomaterial penetration. Part Fibre Toxicol 14:1-16. https://doi.org/10.1186/s12989-017-0211-7

Valodkar M, Jadeja RN, Thounaojam MC et al (2011) Biocompatible synthesis of peptide capped copper nanoparticles and their biological effect on tumor cells. Mater Chem Phys 128:83-89. https ://doi.org/10.1016/j.matchemphys.2011.02.039

Vanti GL, Masaphy S, Kurjogi M et al (2019) Synthesis and application of chitosan-copper nanoparticles on damping off causing plant pathogenic fungi. Int J Biol Macromol. https://doi.org/10.1016/j. ijbiomac.2019.11.179

Wonder E, Simón-Gracia L, Scodeller P et al (2018) Competition of charge-mediated and specific binding by peptide-tagged cationic liposome-DNA nanoparticles in vitro and in vivo. Biomaterials 166:52-63. https://doi.org/10.1016/j.biomaterials.2018.02.052

Worthington KLS, Adamcakova-Dodd A, Wongrakpanich A et al (2013) Chitosan coating of copper nanoparticles reduces in vitro toxicity and increases inflammation in the lung. Nanotechnology 24:1-19. https://doi.org/10.1088/0957-4484/24/39/395101

Xia T, Kovochich M, Liong M et al (2008) Cationic polystyrene nanosphere toxicity depends on cell-specific endocytic and mitochondrial injury pathways. ACS Nano 2:85-96. https://doi. org/10.1021/nn700256c

Publisher's Note Springer Nature remains neutral with regard to jurisdictional claims in published maps and institutional affiliations. 